Editorial

\title{
Large-Scale Urban Developments and the Future of Cities: Possible Checks and Balances
}

\author{
Efrat Eizenberg \\ Faculty of Architecture and Town Planning, Technion-Israel Institute of Technology, Haifa 3200003, Israel; \\ E-Mail: efrate@technion.ac.il
}

Submitted: 14 November 2019 | Published: 21 November 2019

\begin{abstract}
Urban planning deploys large-scale urban development as a preferred strategy in many places around the world. Such an approach to development transforms the urban form, generates new socio-spatial urban relations, and changes planning principles, decision-making and urban power dynamics. This editorial introduces large scale urban development as the current urban policy, discusses possible checks and balances and presents the thematic issue on "Large Urban Development and the Future of Cities."
\end{abstract}

\section{Keywords}

architecture; commercial center; housing; large-scale urban development; neoliberalism; waterfront development

\section{Issue}

This editorial is part of the issue "Large Urban Developments and the Future of Cities" edited by Efrat Eizenberg (TechnionIsrael Institute of Technology, Israel).

(C) 2019 by the author; licensee Cogitatio (Lisbon, Portugal). This article is licensed under a Creative Commons Attribution 4.0 International License (CC BY).

In recent years, we have witnessed dramatic and unprecedented urban growth through large urban developments (LUDs). Relying on complex infrastructure and innovative design tools, LUDs are often promoted as part of general densification plans, and as the way to address both housing demands and environmental concerns. They are sometimes seen as a win-win solution that both supports urban economic growth and fulfils market needs (del Cerro Santamaría, 2019; Gualini \& Majoor, 2007; Swyngedouw, Moulaert, \& Rodriguez, 2002). Such a mode of development is being activated in various urban arenas: tourism, residences, recreation, transportation, education, and commerce, and is being used to shape neighborhoods, commercial centers and business districts.

LUDs engender new planning cultures, new privatepublic relations, new urban demographic transformations and novel environmental concerns. In many instances, LUDs add a dramatic, dominant third dimension to the urban scape; they are built significantly taller than earlier developments (Drozdz, Appert, \& Harris, 2017; Graham, 2016; Graham \& Hewitt, 2013; Greco, 2018;
Talen, 2018). The unprecedented pace with which highrises are emerging, erected individually and in clusters, in cities throughout the Global North and Global South (Nethercote, 2018), has been recently captured as a new 'vertical urbanism' (Harris, 2015).

Neil Smith (2002) suggested that gentrification has become a global urban strategy. LUDs might be seen as the ultimate tool for this end. While such enterprises cater to the needs of the economically viable urban population, they rarely provide remedies for numerous public problems and needs. Advanced as the new urban policy (Gualini \& Majoor, 2007; Swyngedouw et al., 2002), LUDs have, therefore, been critically perceived as the embodiment of the domination of neoliberal market forces over urban development.

Large-scale urban development poses several important challenges to urban scholarship and practice, and requires serious negotiation of the urban planning apparatus: first, to the existing planning framework with regard to urban scale, accessibility, and public-private relations; and second, to its modus operandi vis-à-vis public participation in planning, the dominance of en- 
trepreneurs in urban development, and renegotiating regulations. This contemporary phenomenon of largescale urban transformation led Brenner $(2013$, p. 91$)$ to suggest that "the urban can no longer be understood as a particular kind of place-that is, as a discreet, distinctive, and relatively bounded type of settlement in which specific kinds of social relations obtain." Thus, since contemporary cities are complex, non-homogenous entities, urban theory should focus on "the processes through which the variegated landscapes of modern capitalism are produced" through complex socio-spatial relations (Brenner, 2013, p. 99).

LUDs are a form of making space in the city, space in which to live, work, consume and recreate. In order for urban planning to dutifully reinvent the necessary adjustment and balances, questions should be asked about whom these developments are for, who are the excluded, and what kinds of socio-spatial relations they generate. This thematic issue on LUDs and the future of cities attempts to address these questions and demarcate the challenges they present. The purpose of such an endeavor is not only to expose the failures embedded in large-scale urban development as a dominant urban policy approach, but also to single out the points at which local context, local needs and preexisting frameworks find their way into the process of development and redirect it, or have the potential to redirect it, away from a purely profit-driven end towards a more integrative understanding of various needs. In so doing, it aims to begin to articulate other possible planning practices that may be able to overcome the problem and injustices produced by LUDs.

The issue collects research work on LUDs from three different continents and nine states, namely Cyprus, Denmark, Greece, Israel, Serbia, Slovakia, South Korea, Spain, and the Netherlands. It offers analyses of planning processes, power dynamics, and spatial relations that produce various types of LUDs in different geographical locations. At the same time, by bringing together these different accounts, it establishes LUDs as a microcosm for understanding contemporary local-global, privatepublic, and even North-South interplay and negotiations.

The collection begins with Talen's (2019) insightful commentary in which she utilizes one of the most prevalent manifestation of LUDs-residential LUDs-in order to look critically at present-day neighborhood planning. Talen distills large-scale planning of the 'neighborhood' down to its familiar and more implicit guiding elements. She proposes the ought-to-be practices that balance local, small-scale planning that includes bottom-up input, with larger, more comprehensive approaches to neighborhood planning.

In "Post-Socialist Urban Futures: Decision-Making Dynamics behind Large-Scale Urban Waterfront Development in Belgrade and Bratislava," Machala and Koelemaij (2019) unpack entrepreneurial decisionmaking regarding LUDs in post-socialist capitals Belgrade and Bratislava. Waterfront LUDs processes in these two cities are compared in order to highlight a complex dy- namic between local particularities and more global domineering forces. They show how particularities are ultimately flattened to pave the way for urban growth dictated by private interests.

Israel, characterized by hyper-neoliberalism and extensive large-scale development, is subjected to three critical accounts. The first is by Weinberg, Cohen, and Rotem-Mindali (2019), "LUD as an Instrument for (Sub)Metropolitanization: The 1000-District in RishonLezion, Israel as a Case Study." It offers a critical account of the neoliberalization of planning processes and investigates the process of planning a new multi-purpose LUD in a secondary city at the center of Israel. Tracing the development of the planning process, the authors show how a project that was aimed at addressing local needs evolved over time into a marketing tool to reposition the city as a sub-metropolitan center.

On the same theme of negotiating the influence of neoliberalism on local planning decision-making, "Large Urban Developments as Non-Planning Products: Conflicts and Threats for Spatial Planning" by loannou, Nicolaou, Serraos, and Spiliopoulou (2019) examines how in post-economic crisis Greece and Cyprus, LUDs are promoted as a means of attracting foreign investment. Overlooking local problems and needs, planning policies bypass spatial planning frameworks, making flexibility a determining factor in the approval of LUDs. Thus, the capacity of urban investment in LUDs as a solution for local problems is interrogated.

In "Housing in the Neoliberal City: Large Urban Developments and the Role of Architecture," Majerowitz and Allweil (2019) illuminate relations between neoliberalism and LUDs as manifested in the architecture of residential LUDs. Through a case study analysis of the architecture of featured residential LUDs in Israel, the Netherlands, Denmark and Spain, they unravel the tension between variety and multiple choice on the one hand, and uniformity and replication on the other hand. By analyzing elements of design, they demonstrate how design is used as a marketing tool by differentiating certain residential LUDs from the 'standard.'

Residential LUDs, as noted, stand out in their magnitude and visibility. In "Neoliberalism Meets "Gangnam Style": Vernacular Private Sector and Large Urban Developments in Seoul," Park (2019) examines the evolution of residential LUDs in South Korea up to their present-day domination of the housing market. Focusing on the wealthiest and most dense district, Gangnam, the article shows how while Western planning concepts are enthusiastically deployed, sometimes without constraint, they nonetheless remain in negotiation with local, more traditional urban systems and concepts, thereby begetting hybrid urban forms, which Park refers to as 'vernacular neoliberalism.'

Finally, LUDs are not only producing new relations between urban actors, new forms, and new planning process and principles, but also new urban spaces. In "Urban Morphology and Qualitative Topology: Open 
Green Spaces in High-Rise Residential Developments," Eizenberg, Sasson, and Shilon (2019) offer a typology of the open space produced in residential LUDs in Israel. Their analysis of the spaces between the buildings, used for recreation, parking, and ornamentation, offers, in addition to their morphology, indicators with which to evaluate the overall diversity, accessibility and green quality of a residential LUD complex. The juxtaposed analysis of how these spaces are perceived and experienced by users provides important planning insights into their scale and composition.

\section{References}

Brenner, N. (2013). Theses on urbanization. Public Culture, 25(1), 85-114.

del Cerro Santamaría, G. (2019). Megaprojects, development and competitiveness: Building the infrastructure for globalization and neoliberalism. Athens Journal of Social Sciences, 6(4), 263-290. Retrieved from https://www.athensjournals.gr/social/2019-64-1-Santamaria.pdf

Drozdz, M., Appert, M., \& Harris, A. (2017). High-rise urbanism in contemporary Europe. Built Environment, 43(4), 469-480.

Eizenberg, E., Sasson, O., \& Shilon, M. (2019). Urban morphology and qualitative topology: Open green spaces in high-rise residential developments. Urban Planning, 4(4), 73-85.

Graham, S. (2016). Vertical: The city from satellites to bunkers. Brooklyn, NY: Verso Books.

Graham, S., \& Hewitt, L. (2013). Getting off the ground: On the politics of urban verticality. Progress in $\mathrm{Hu}$ man Geography, 37(1), 72-92.

Greco, E. (2018). Questioning the vertical urbanization of post-industrial cities: The cases of Turin and Lyon. Built Environment, 43(4), 555-570.

Gualini, E., \& Majoor, S. (2007). Innovative practices in large urban development projects: Conflicting frames in the quest for "new urbanity." Planning Theory \& Practice, 8(3), 297-318.

Harris, A. (2015). Vertical urbanisms: Opening up geographies of the three-dimensional city. Progress in $\mathrm{Hu}$ man Geography, 39(5), 601-620.

loannou, B., Nicolaou, L., Serraos, K., \& Spiliopoulou, G. (2019). Large urban developments as non-planning products: Conflicts and threats for spatial planning. Urban Planning, 4(4), 31-42.

Machala, B., \& Koelemaij, J. (2019). Post-socialist urban futures: Decision-making dynamics behind largescale urban waterfront development in Belgrade and Bratislava. Urban Planning, 4(4), 6-17.

Majerowitz, M., \& Allweil, Y. (2019). Housing in the neoliberal city: Large urban developments and the role of architecture. Urban Planning, 4(4), 43-61.

Nethercote, M. (2018). Theorizing vertical urbanization. City, 22(5/6), 657-684.

Park, J. (2019). Neoliberalism meets "Gangnam Style": Vernacular private sector and large urban developments in Seoul. Urban Planning, 4(4), 62-72.

Smith, N. (2002). New globalism, new urbanism: Gentrification as global urban strategy. Antipode, 34(3), 427-450.

Swyngedouw, E., Moulaert, F., \& Rodriguez, A. (2002). Neoliberal urbanization in Europe: Large-scale urban development projects and the new urban policy. Antipode, 34(3), 542-577.

Talen, E. (2018). Neighborhood. Oxford: Oxford University Press.

Talen, E. (2019). Large urban developments and the future of cities: The case of neighborhoods. Urban Planning, 4(4), 4-5.

Weinberg, E., Cohen, N., \& Rotem-Mindali, O. (2019). LUD as an instrument for (sub)metropolitanization: The 1000-District in Rishon-Lezion, Israel as a case study. Urban Planning, 4(4), 18-30.

\section{About the Author}

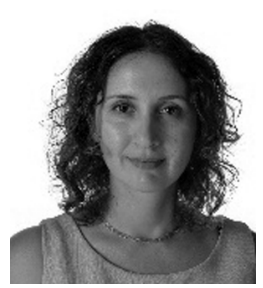

Efrat Eizenberg, PhD in Environmental Psychology, is an Associate Professor at the Faculty of Architecture and Town Planning at the Technion, Israel. Her research topics include urban regeneration and development, urban open spaces, planning with communities, and planning research methodologies. She is the author of From the Ground Up: Community Gardens in New York City and the Politics of Spatial Transformation, published in 2013 by Routledge. 